\title{
Fonologia e Fonética na Universidade: uma experiência
}

\author{
Phonology and Phonetics at University: An EXPeriment
}

Nara Hiroko TAKAKI*

Resumo: A atitude pós-estruturalista concebe o mundo como processos de transformação. Embora essa noção não seja novidade, profissionais da linguagem preocupam-se em elaborar alternativas que expandam estudos relacionados a fonologia e fonética em meio à cidadania educacional e global. A partir disso, este trabalho apresenta uma visão mais holística do ensino-aprendizagem de língua e relata uma experiência como alternativa para a fonologia e fonética da língua inglesa em meio às práticas sociais. Essa descrição é parte de um projeto maior sobre a construção de sentido multimodal do aprendiz por meio de tecnologia em contexto de universidade no Brasil. O resultado dessa experiência reforça a integração de fonologia e fonética numa disciplina, Uso de tecnologia no ensino de línguas, em que aprendizes graduam em Inglês, Português, Espanhol e Literaturas.

Palavras-chave: Fonologia e fonética do inglês. Prática social. Universidade.

Abstract: The post-structuralism attitude sees the world as processes of transformation. Although this notion might not sound like a novelty, professionals of languages grapple with alternatives to foster studies related to phonology and phonetics within more global education citizenship. From this assumption, this paper presents a more holistic view of language teaching-learning and reports an experience as an alternative to the practice of phonology and phonetics of the English language within social practices. This is a report of a larger project on the learner's multimodal meaning making

\footnotetext{
* Doutorado (2008) e pós-doutorado (2012) em Letras Modernas (Português e Inglês) pelo Programa de Estudos Linguísticos e Literários da Universidade de São Paulo. Professora adjunta II da Universidade Federal de Mato Grosso do Sul. Contato: bobnation@terra.com.br.
} 
through new technology in the context of University in Brazil. Results from such an experience reinforce the integration of phonology and phonetics in the discipline: Use of technology in language teaching, whose under-graduates are majoring in English, Portuguese, Spanish and Literatures.

Key words: Phonology and phonetics in English. Social practice. University.

\section{Introduction}

This paper presents some pedagogical and epistemological practices of student's meaning making and agency through the use of the English language and new technologies in the context of public Brazilian Higher education. It is part of a broader research project whose aim is four-folded. First, the goal is to investigate the assumptions that underlie exploratory, multiple and alternative paths for collaborative syllabus design and transnational knowledge construction for the disciplines I have been teaching such as: Technology and language learning, English language; English language teaching practice and Special topics in Applied Linguistics (Master course). Secondly, it examines learners' production in rbizomatic education model (DELEUZE; GUATTARI, 1987, p. 21), which can be translated into learning experience and agency, creativity and critique. Thirdly, it seeks to reconnect classroom literacy practices with the changes in the learner's daily lives and routines as signaled by current transnational citizenship and education (BRYDON, 2013) towards a more inclusive and transformative foreign language teaching-learning at university (MORGAN, 2013). Last but not least, the ultimate goal is to stimulate higher education learners to construct personal perspectives within interdisciplinary subject matter in a multimedia format. This means creating opportunities for languages practices and for sharing agency and world views through performance supported by the new literacies, multiliteracies and critical literacies theories.

To this end, a selection of multimodal tasks have been designed and implemented by the researcher of this project who is also the paper's author. Some findings have been collected and the expectations include discussions on epistemological implications in 'class capes' as insights to resignify official university social practices emphasizing the place of phonology and phonetics within curricula, language politics. The dissemination of these learner's productions occurs in seminars in classes, academic events, by word of mouth 
and on Facebook. As the world of business capitalize on new expertise, on the multiplicity of oralities and initiative from young workers, this raises the critical question of why not expand that in post-critical education for digital societies?

\section{Methodology, Setting and Participants}

As asserted by Van Lier (1988), among others, getting to know about cultures requires an ethnographic qualitative and interpretive perspective. This means observing an environment of research, which is the classroom in the case of this experience, considering the daily behavior of the local participants, who are co-authors of meanings. The methodology used emphasizes the need to expose the learners to the theoretical framework and procedures for tasks to be produced either in groups or individually. The data generated from such tasks might signal the expansion of exploratory research methodology (TAKAKI, 2013) as participants work in the spirit of explorers, redesigners of meanings, performance, Arts. To understand the complexity of the social practices, not only the learners' multimodal productions, views and values are taken into account, but also the researcher's choice of theories and ways attributing meanings to the text and world.

I also resorted to Kumaravadivelu's (2006) three principles of the post-method era such as: a) particularity as a look into/at what is relevant for the group investigated, their realities and interests: a) practicality understood as the participation of teachers and learners and c) possibility as a form to conduct research and pedagogical practices to foster autonomy within the participants in ways that can change their epistemologies and act for communities of literacy practice towards more dialogical renegotiations of meanings, transforming power inequality via global education citizenship.

In this way, the situation reported here has been conducted in an under-graduate program for English/Portuguese/Spanish students at the Federal University in the State of Mato Grosso do Sul, Brazil. The discipline in question was Use of technology in language teaching, taught by myself. It was attended by learners influenced by multiethnic aspects from the frontiers of Bolivia and Paraguay, by indigenous communities and communities of migrants from all over the country.

The class was comprised of 25 students, some majoring in Portuguese and English, others in Portuguese and Spanish, and others in Portuguese 
language and Brazilian and Portuguese literatures. This led me to work on theoretical articles in the three languages for each group. They were supposed to read and share the ideas in their particular groups and then open the discussion so that the whole class could join in and get engaged in the debates, which generated dynamic interaction in a visible cross-cultural context.

For the aim of this paper, I will concentrate on the learners of English. They were familiar with phonological and phonetics features such as pronunciation, intonation, stress, rhythm, from the previous disciplines, Phonology I and Phonology II taught by a colleague in previous terms.

In addition to this, they were familiar with social networking, use of mobile phone in twenty-four hour education out of the university environment. Some of them showed other capacities such as: playing a musical instrument, singing, teaching English at kindergarten or at private English schools. Other learners worked at public institutions or for non-profitable organizations and others were scholarship holders. Projects including use of English, Portuguese as additional language or Spanish in video clips were most appreciated by these young learners according to their feedback in our last encounter.

The core idea was to produce video clips imbued with the use of digital technology within languages. This presupposed theories of new literacies, multiliteracies and critical literacies (NEW LONDON GROUP, 1996; GEE, 2004; LANKSHEAR; KNOBEL, 2005; KALANTZIS; COPE, 2012) and such theories were no longer new to them, as they had participated in lectures and events by experts in the aforementioned subject matters, read papers from specialized journals and attended sessions in my study group, as extra classes, throughout the past three years. Literacies represent a set of studies that comprises a series of verbal, non-verbal and verbal-visual relations in meaning making as a social practice within multimodal language, unequal distribution of power, decision making, adjustments, adaptations, cultural translations, understanding each one's views and renegotiation of meanings towards transnational attitude.

A large repertoire of situatedness of elements such as cross-borders configurations (varied and complex changes ascribed to Englishes worldwide), the coexistence of local and global perspectives, sense of ethical citizenship, the use of multimodal language, critical thinking, the epistemological expansion (in the sense of constructing other realities other than those already known and validated historically by dominant views and social groups) were negotiated 
with the learners, during and after the discussion of the texts that they were supposed to read in advance. Research (MONTE MÓR, 2006) indicates that students majoring in Portuguese and English, in a four-year course, rarely have the opportunity to transpose into digital environment what they already know, can do, in terms of meaning making and performance. Bearing this in mind, I decided to focus on features related to phonology and phonetics as contingencies demanded. It turned out that this experience revealed paths that might renew practices for such studies in more interdisciplinary mode.

To reiterate that social practices are conceived of as political forms of inactment, in producing the video clips learner's knowledge construction compete with other knowledges in unequal ways, struggling to maintain their positioning and multimodal creations in relation to the other's views. Learners tried to validate their perspectives through fostering possibilities for agency and autonomy, as external observer would astutely perceive.

At the end of the term, they were supposed to present their work to the whole class and listen to their peers' feedback, which turned to be very productive in terms of inclusive and transformative ways of working on phonology and phonetics to nurture higher education and to fulfill the demands of present times. Central to this notion of language as a social practice, within the complex diversity in language, conventional and integrated practice of phonology and phonetics (rather than totally separate disciplines), is of the utmost importance.

\section{Phonology, Phonetics and Language as a Social Practice}

The development and practice of a living curricula or syllabi together with critical pedagogical multimodal practices in ELT, World Englishes (the different varieties of English and English-based creoles developed in different regions of the world), International English, primarily used in international contexts (JENKINS, 2009), World English (RAJAGOPALAN, 1997, 2004), English as lingua franca (for business, trade, diplomacy and other global activities) are not relatively new, considering the influences of the westernized fashions of teaching which mostly emphasize written and oral productions (PENNYCOOK, 2007).

Constant exposure of audio materials and video productions with a view to enhance students' comprehension is essential when it comes to understanding different accents, rhetorics, and the ability to interpret parodies, 
ironies, subtle ideas, ambiguities, in-between-the-line notions, complex identitary reconstructions and world views. Recent news report the insufficient performance by Brazilian students in English exams while applying for scholarship exchange in undergraduate and graduate programs in various fields of knowledge in English speaking countries. ${ }^{1}$

A transitional phase in Brazilian education sheds light to the importance of learners reading, interpreting, producing, renegotiating and disseminating multimodal texts with the use of technology and theoretical underpinnings from digital critical literacies. A critical articulation then of how oral, written, visual-verbal texts can be produced, interpreted and renegotiated is expected, going beyond the basic notions of phonology and phonetics. Such basic notions seem more adequate for basic education programs.

In many contexts, the paradoxes remain: learners are not particularly capable of working critically on multimodal and digital texts, while being assessed through print-based texts. At the same time, they are now challenging their teachers' digital epistemologies, technical abilities, meaning making and agency. Paradoxes such as these require further studies and time while historical practices, epistemologies, resources coexist with novelties in transformative ways (PENNYCOOK, 2007). As previously mentioned, exposure to a twenty-four hour education out of the school or university has been impacting the development of children, young learners and adults. This constitutes a vision of many classroom situations at primary and secondary school education, in which the learners of English may not necessarily become teachers of English.

Nevertheless, undergraduate students seeking to major in English are expected to get to know of/about the principles, rules of conventional phonology and develop a large repertoire of their practices. Thus, there are different practices connected to such disciplines in different situations.

1 The weak English language performance of Brazilians who apply for vacancies in the Science without borders program made the Brazilian government lower the score requirement from 72 to 42 in the Toefl examination. Out of the 4 thousand scholarships available in the State of São Paulo, only 1,8\% (45\%) were held. My translation from the original text in: <http://noticias.terra.com.br/educacao/ governo-baixa-exigencia-de-ingles-para-vagas-do-ciencia-semfronteiras,fe940030d14bc310VgnVCM20000099cceb0aRCRD.html>. Access: 10 Feb. 2013. 
In my particular context of teaching, the direction signals learners' authorship and an increase production of oral English as they are prone to constructing knowledge using their technical abilities, talents, critique, creativity, awareness of diversity, local-global resources and interconnections, ethics, and knowledge of the world. This reiterates how crucial knowledge and practice of phonology and phonetics is.

These young learners produce, direct, edit and re-edit their own video clips with multimodal narratives challenging reductionist epistemologies and disseminate their own "accents" in phonological and phonetics features that are far from being unintelligible for many speakers of English worldwide, I would dare to say. They have the opportunity to achieve a sense of ownership of their "accents" but not in their own rights per se. Instead, they reconstruct the idea that meaningful negotiation is possible through various accents as long as the group member share the minimum conventionalities and norms generated locally and sufficiently understandable by global speakers within particular contexts of performance. Language is seen as performance not pre-formed as Canagarajah (2005) postulates.

Unarguably, learning, unlearning and learning again by practicing, experimenting with a multimodal pedagogy of phonology and phonetics may be at stake in face of the post-method attitude (KUMARAVADIVELU, 2006) to attend differently to the increasing diversity as already stressed here. This can be a significant differential if we compare traditional ways of dealing with phonology and phonetics based on imported materials, syllabi, evaluation, all of them, usually, elaborated in top-down manner and, thus, strongly influenced by English native speaker's models, ideologies, social practices and agencies. Phillipson (1992) argues the spread of the English language threatens other local languages, cultures and identities and one may ask whether these other languages need to be safeguarded. My group of students does not agree with that as they reinforced during the discussions in class. However, this question merits further research.

By extension, tasks to innovate pedagogical practices in classes imply the assumption that literacies are totally immersed in learners' background, language, accent, context, purpose and discourse of the text in question, which are founded on social practices (STREET, 2005).

Moreover, as a new mode of meaning making and multisemiotic reflexive composition, video clips cannot be limited to personal narratives as they allow for argumentation, illustration, positioning, agency, attitude towards 
what is happening around oneself and around the others. They have evolved as a set of hybrid and complex genres with past experience whose significance the learners want to explore and share their critical thinking about a specific subject matter.

The multi-skilled, multi-task learner create parodies, stories, narratives or other representations that should not be understood as a phenomenon equivalent to written narratives or mere oral storytelling transposed to the digital screen. It is not a simple transfer of content from one medium to another, for it implies a series of complex and dynamic multimodal elements. The situation stresses the creation of space for conventional practices of phonology and phonetics and their theoretical framework embedded in their broader social surroundings.

\section{Convergence of Phonology and Phonetics: an experiment}

Phonology has been defined as the study of the sound systems of languages. It is concerned with anatomy and physiology, that is, the organs of speech, how speakers learn to use them. Part of the subject is imbued in socio-linguistics, which means social attitudes and cultural practices influence the characteristics of accents and intonation. It also searches for standard ways of recording speech, representing it through symbols (ROACH, 2008). Crystal clarifies the aim of phonology as a means:

To discover the principles that govern the way sounds are organized in languages and to explain the variations that occur. We begin by analyzing an individual language to determine which sound units are used and which patterns they form the language's sound system. We then compare the properties of different sound systems, and work out hypotheses about the rules underlying the use of sounds in particular groups of languages. Ultimately, phonologists want to make statements that apply to all languages. (CRYSTAL, 2005, p. 28).

On the other hand, phonetics, according to Ladefoged (2001), is the science which studies the sounds used in human language. A branch of phonetics, the articulatory phonetics, analyses the physiological and articulatory aspects of the speech production. It describes, classifies and transcribes the 
sounds produced. Both phonology and phonetics function as basis for additional work in morphology, syntax, discourse, and orthography design, complemented with recent studies of the new literacies.

As the way the sounds of a particular language are organized, depend very much depend on the language users. In this way, it is desirable to promote the teaching-learning of phonology and phonetics with insights to: a) raise student's awareness of the differences, contrasts, similarities among Englishes and Portuguese sounds and their corresponding spellings; b) describe the manner and place of the sounds, phrases, sentences through repetition and different strategies; c) work on articulatory muscles to improve performance; d) practice sounds in paragraphs and dialogs; e) know about the phonetic alphabet, symbols and transcription, depending on the user's needs and interests; g) check and monitor "progress" to promote autonomy; f) work on different online/offline pronunciation dictionaries and other audio/digital resources.

In face of the new technologies, social networking with the use of Skype, YouTube, cameras, mobile phone and interactive electronic games, can only favor a multiplicity of experience and practice of oral and written Englishes, as learners' success can no longer be defined solely as proficiency in this or that kind of English (e.g.: American, British). Other themes arising from this orientation refer to the deconstruction of polarized notions such as: standard $\mathrm{x}$ non-standard; target $\mathrm{x}$ fossilized; language $\mathrm{x}$ interlanguage to rethink a geopolitical perspective to incorporate responsibly local hybridities. Given the dynamic and uncontrollable transnational fluxes of ideas, goods, travels, business, learners are required to commute in different spaces and renegotiate meaning effects in discourse embedded in specific sociocultural and interpersonal contexts (SEIDLHOFER, DALTON, 1995; CANAGARAJAH, 2005). Hence, there are compelling reasons to outline multiple pedagogies to maintain local and complex identities, preferences and reflexivity of decisions and their implications in other forms of meaning making.

Due to the fact that studies related to complexity of globalization (APPADURAI, 1996; MIGNOLO, 2000), a discernible view would infuse curricula with discursive reconstructions, refashion identities, for a variety of different epistemological claims/goals as agentive acts to rethink what effects contrasting different methodologies and epistemologies permeated by phonological and phonetic features might have on multilingual citizenry. 
Apart from this arena of complexity, phonology and phonetics might appeal to learners when approached along with an awareness of conflicting interests and ideologies permanently at play, in inter-trans-cultural contexts, as social practices not mere disciplines isolated from each other. They represent insights for teachers, students and researcher's choices as regards what, how, why phonology and phonetics should be approached/conducted in particular settings so as to avoid the work of linguistic aspects for its own sake.

Following this trend, Jenkins' study (2009) is indicative of other preferences. She suggests where speakers are not able to produce the sounds $/ \theta /$ and $/ \partial /$, other approximations such as $/ \mathrm{t} /$ or $/ \mathrm{d} /$ could be used, what would neither impede communication nor put a strain on the general interlocutor. Other sounds that represent examples of predictable phonological issues for Brazilian learners include: $/ \Lambda /$ and $/ \mathrm{m} /, / \mathrm{n} / ; / \mathrm{n} /$ at the end of the words (SILVA, 2012; GODOY; GONTOW; MARCELINO, 2006; ZIMMER; SILVEIRA; ALVES, 2009). These authors attest that Brazilians, in general, have good pronunciation in English. Both receptive and productive masteries of different varieties of English should be stimulated, towards intelligibility (MORLEY, 1994), though.

Many professionals of the English language may consider the importance of reducing foreign accent that might hamper communication by applying to meaningful guided practice, exercises involving individual sounds and phrases to dialogs and contextualized listening or reading passages followed by discussions on the themes presented with the use of multimedia and other increasing comprehension listening skills while encouraging self-monitoring strategies.

A critical attitude seeks to undermine the notion that foreign accent is inferior. Even though, one may argue that what is intelligible for one speaker may not be for the other(s) (RAJAGOPALAN, 2004), this does not mean non-native speakers cannot produce meanings qualitatively to accomplish their goals in specific contexts.

As Smith and Rafiqzad's (1979, p. 57) advocate: "since native speaker phonology does not appear to be more intelligible than nonnative phonology, there seems to be no reason to insist that the performance target in the English classroom be a native speaker". Widdowson (1994), Crystal (2005) and Graddol (2006) reinforce the idea that native speakers are no longer the norm providers or owners of their language. Non-native speakers will have to 
become more flexible to get along with more varieties of English and new forms of relationships.

Also, Kramsch (1993) has reminded us that it is simplistic to undermine the differences among native speakers and, thus, the concept of circles (inner, outer and expanding circles) by Kachru (1982) seems unrealistic not only for such an author but also for Pennycook (2007). In this sense, technologies can accelerate such oral, multimodal exposure and practice expanding meaning making, its evaluation and renegotiation in cross-cultural contexts permeated by uneven power relations (SHOHAMY, 2004, 2006).

\section{Initiatives to Enhance Phonology and Phonetics within Undergraduate Social Practices}

It was mentioned at the outset that one of my aims in writing this paper is to report an experiment as illustration of possibilities to deal with phonology and phonetics that seem to be more congruent with the demands of a pluralized world.

From my experience, producing video clips is one of the most productive activities which allows users to chat with others, work with new friends, collaborate and use them as a tool to practice oral English, and mainly, to construct and renegotiate multimodal meanings (KRESS; VAN LEEUWEN, 2001) and their effects from a critical stance. This presupposes being exposed to the theoretical basis as already clarified here. Technology has made kids, young learners and adults more co-operative, creative and sophisticated in their narratives. This means strategies are developed towards joint tasks, or else, multitasks (dealing with multisensory information while transforming it into relevant knowledge) which, in turn, have enhanced the transformation of ways of learning by producing relevant videos locally, in the case of this paper.

As a result, such a production creates a community of social and multimodal practice from an educational, critical and creative perspective. When receiving comments and suggestions, learners can improve their oral work, showing and sharing their different talents and ways of seeing and participating in the world. 
I focus on one single example of a video clip produced by a student: $\mathrm{Gil}^{2}$ is the author of the parody I describe and discuss here. With this combination of assets and practices of literacies, the video starts up with Gil holding his guitar while addressing the general public, explaining the reason why he has produced his work as a multimodal composition. He is seated next to a TV set, on whose screen the viewers can see an imagetic narrative connected to the parody ${ }^{3}$ he has made of a popular song ${ }^{4}$.

What strikes as relevant in his narrative construction is the choice of images (he himself playing football, wearing the national team uniform), the figure of a teacher of English speaking to the class when no one was interested in his/her lesson. This is followed by a sequence of students who end up falling asleep on their desks. An empty stadium is shown with Gil sitting, thinking otherwise by sustained reflection and feeling a kind of nostalgia of a country which in principle had/has the capacity to prioritize education not only the Football World Cup. It suggested his critical thinking by comparing the status of the teaching of the English language in Brazil and the status of its professionals with the tremendous investment in the so called World Cup.

This complex presentation depicts the way he resignifies the original song "Have you ever seen the rain" while playing and performing what he had redesigned by using technology, language, critique and creativity: a parody criticizing the teaching of English, the pace with which it is taught at public schools. He mediates critique by also resorting to such a discursive genre, calling for more attention to research, to the professionals of the English language around Brazil. Emphasis is placed on the image some foreigners

${ }^{2}$ Gil is a nickname to protect the producer's anonymity. He is also a singer, guitar player, bus driver for the Municipal bus lines at his town, taking teachers and students to indigenous communities during the day. At night, he goes to a language course (Portuguese and English languages) at the aforementioned university. When interviewed on how he started to develop his potential, he said he had and has developed this kind of bottom-up exploratory attention, rapid attention switching, distributing attention in multiple places and focuses in ways that resemble the dynamics in local traffic, personal choice of music, languages and technology.

${ }^{3}$ A piece of writing, music etc. or an action that copies someone or something in an amusing way, <http://www.ldoceonline.com/dictionary/parody_1>.

${ }^{4}$ The original song is 'Have you ever seen the rain', first recorded by Creedence Clearwater Revival and later by Rod Stuart. 
construct about Brazil due to the waiters' insufficiency in/no English at all to provide the tourists with some assistance, as the excerpt below shows:

Hello!

This video is a parody about the teaching of the English language, some research and the image some foreigners have about Brazil.

I tried to do review of the slow foreign language education in the regular school currently, with the number of professionals who have mastered the English language in public places or tourist sites around the country.

A popular local TV channel showed this deficiency a few days ago in the World Cup confederations. Some tourists felt angry at the bars and restaurants in some Brazilian cities as they could not be understood by the Brazilians.

So, I made a parody of the song "Have you ever seen the rain" by Creedence. The song tells a story of a native speaker of English who came to Brazil for the World Cup and could not have dinner in a restaurant because the waiter did not understand him. Come on, then....

The parts in bold in the connected speech above are the ones that "needed" improving in terms of more clarity ${ }^{5}$ in pronunciation, although the way they were uttered would neither put a strain on the viewers nor impede total recognition of the string of phonemes in question. Therefore, communication of his idea within that particular context would be quite easily converted by the general hearers. When addressing the viewers, Gil used more muscular energy resulting in prominence of the second syllable in the word image (/I'mId3/) ${ }^{6}$ instead of in the first one (/'ImId3/); in foreigners, he dislocated the stress to the second syllable (/fn'ronəz/) instead of emphasizing the first one (/'fpronəz/).

As usual, there is always a peer who tends to be more "perfectionist" and with no further delay prompted to "correct" Gil:

${ }_{5}$ According to the Received Pronunciation, RP.

${ }^{6}$ I resort to the International Phonetic Alphabet, IPA. 
Laila $^{7}$ : Image, Gil. (Stressing the length, pitch and quality of the first vowel)

Gil: Image, ok. (He follows her model)

Laila: And it's foreigners not foreigners. (Underlying the primary stress)

Gil: Foreigners. (He repeats her model)

I also realized Gil's positive attitude welcoming Laila's feedback and felt willing to get to know more about the areas he could improve. He was capable of perceiving the stress marks and repeating the words successfully.

Concerning the words currently and country, the vowel and the diphthong were pronounced respectively like: /u/ and /av/, resonating typical Brazilian beginners' productions (and some more fluent students). Maybe due to the fact that transferring experience from previous accurate practices is not something done automatically, associating the vowel height, that is, open-mid back (tongue positioned half way between and open vowel/low vowel and a midvowel) or low-mid back (the tongue is positioned as far back as possible in the mouth without creating a constriction) unrounded (the lips are not rounded) vowel $/ \Lambda /$ in /'k $\Lambda$ rəntly/ and /'k $\Lambda$ ntrI/ with words such as but, cut, etc. may not have been naturally for him. Another hypothesis could be that Gil related / $\mathrm{v} /$ in currently as it happens in words such as butcher, bush. Or, he may have thought this sound would be similar to the sound in counter /'kauntor/, alluding to the fact that the relationship between spelling and pronunciation is complex.

As the subsequent lyrics highlight, Gil goes on to show how angry the tourists got at the Brazilians in a bar or restaurant. Probably the staff could not communicate with them in English or utter the minimum to strike a conversation for survival purposes. In this connected speech, the first vowel in angry (/'æygrI/) is mispronounced resulting in something similar to /a:/ instead of $/ \mathfrak{x} /$. He stresses the stress first syllable, though. In spoken (/'spəukən/), the nasal and alveolar consonant phoneme /n/ disappears while producing the linking between /n/ and /I/ (consonant + vowel) in Have you ever spoken English? Gil probably knows that the past participle form of the verb speak is spoken. He may have had difficulty in articulating both point and manner of articulations of this particular sound, in connected speech,

${ }^{7}$ Laila and Gil are nicknames. 
to let the air come out through his nose lowering the soft palate, controlling the nasal process and linking it with the subsequent vowel sound in the beginning of word English.

Someone told me long ago

The country for football is Brazil

I know

But they don't speak English

When the World Cup starts

And I've gone to Brazil

I won't know

How to ask a waiter

I wanna know

Do you understand me?

I wanna know

How much is dinner and an orange juice?

I can't speak Portuguese

The teaching is insufficient

And the people are paying for this

I know

Maybe they will learn it one day

But while this does not happen

I'm here starving in this place

I don't know

What language I must speak

I wanna know, waiter

Have you ever spoken English?

I just wanna know

How much a sparkling water is, please

I can't speak Portuguese 
The performance did not convey a difference in terms of meaning. It would be satisfactory if Gil's physical nature of his speech sounds (phonetics) was left the way it was initially. Furthermore, the way he organized and stored the knowledge of the sounds enabled him to use it appropriately on most occasions (phonology).

As a stress timed language, English(es) also require(s) such learners to be exposed to suprasegmental features. While revising the question of stress, the learners showed knowledge, for example, through saying that "if the stress is phonemic, there will be a change in meaning with a change in stress, if there is no change of meaning, the stress is phonetic." In this sense, intelligibility depends more on suprasegmental units of language such as: prosodic elements as length, tone, intensity, melodies, rhythm, and intonation, as well as markers indicating the juncture of segmental units rather than on the "correct" pronunciation of syllable by syllable or word by word (HOLLIDAY, 2009; LODGE, 2009).

At the same time, expanding the development of oral practices was vital. Instead of 'modelling' the pronunciation of such words to him, I asked the class to sing along this song so that Gil could perceive clearer pronunciation of such words/parts. If I had made him repeat those particular sounds and words, as in conventional ways, the process would be teacher centered and the class might have had less initiative to practice their oralities, functioning as collaborators. Singing along was a pleasant procedure, and overt instruction was not necessary. Gil's final recording shows he had improved considerably. I suggested he shared the video clip on YouTube and he accepted it. However, this has not happened yet.

Of the many advantages of creating spaces for learners' multimodal productions using what they can already do and enjoy doing, such as this video clip, is the fact that high and low varieties of level tones (suprasegmental features) can be more easily practiced when the learners have a reference to resort to; in this case, Gil's intonation, melody, pitch were based on the original song. Phonology and phonetics teaching-learning is said to be really one of the various and complex components integrated with communication in its broader sense (SEIDLHOFER; DALTON, 1995; CELCE-MURCIA; BRINTON; GOODWIN, 2008). Nevertheless, Gil seems to be actively engaged in doing what makes sense to him in pleasant ways to "refine" his English, not as a myth, but to suit purposes that are not decided upon/imposed by the center, by the professor, by the native speakers. Without giving up his own identity, culture, he produces meaning critically in his English. 
In sum, this task is the product of Gil's agency, creativity, identity and he was able to combine literacies, phonology and phonetics as social practices within a particular discursive sort of genre: the parody.

Contrary to what Professor Higgins ${ }^{8}$, who would never, ever, believe that a florist, Elisa, would be able to learn the queen's language and, therefore, resort to mechanical repetitions of meaningless phrases to be repeated ad nauseam by his student; contrary to Professor Frank ${ }^{9}$ who would not believe a hairdresser, Rita, would be able to enter and finish university, both the bus driver (author of the video clip) and the professor (author of this paper) chose a different direction; to reconstruct collaboratively an alternative in which the learner could use what he already knew (Gil had already presented other parodies in a local academic event at the university) and got engaged in a differential performance in order to share what made sense for him and, hence, contribute to more meaningful lessons on phonology and phonetics, that is, a social practice within literacies and literacies and vice versa.

When new literacies are used with sensibility, sensitivity, they offer teachers new learning possibilities (KALANTZIS; COPE, 2012). From a political point of view, Gil, in the tourist's place, generalizes the fact that people in Brazil do not speak his language: "they don't speak English." An inquiry emerges "What language I must speak?” acknowledging that being a monolingual speaker is disadvantageous and no longer fulfills the requirements of a post-modern society, specifically in a context in which the Football World Cup is to be held. An ambiguous positioning or identity is, then, presented as the author/singer/ performer/bus driver/ football player/teacher to be puts himself in the foreigner's shoes.

In this sense, Gil's attitude towards meaning making through multimodalities, critique and creativity in more autonomous ways, running his own business of challenging identities, circumstances, of English teaching-learning and its consequences deeply entrenched in national and

${ }^{8}$ Character of the play Pygmalion, a play written by Bernard Shaw and presented for the first time in 1912. The film My Fair Lady is an adaptation launched in 1964. For further critical interpretive studies on both films in English classes, refer to Takaki, 2011.

${ }^{9}$ Character of the film Educating Rita. For further critical interpretive studies on both films in English classes, refer to Takaki, 2011. 
transnational contexts. His ethical, critical thinking and oral performance stem from various sources: a) his access to oral English through the new technologies and at university; b) the epistemological and multimodal input he has received and co-constructed in lessons and lectures, organized at university; c) his artistic vein as a singer, music player, parody creator, composer, bus driver, meaning maker and speaker of English, social purpose and capacity to work in networked style throughout his project.

A key point worth mentioning is the difference between input/information and knowledge. The former is characterized when, for example, the learner is exposed to information with no further interest to go beyond the level of data, either because of his/her lack of familiarity in relation to the subject matter or because of lack of interest or incentive. In this case, information is hardly ever transformed into knowledge. The latter, requires the learner to observe, listen to someone, analyze, interpret, in short, to interact with and challenge the information by attributing meanings to the information in question from his/her social background, his/her position in society, his/her values, assumptions, experiences and other knowledge he/she has constructed throughout his/her social practices.

He was acclaimed by his peers, who congratulated him on such a productive use of multimodal narrative integrating a TV screen and the video clip, the production of complex knowledge, which sketched out areas of English, Arts, Geography, Cultural Studies, Sports, ICT, Literature, Music, History, towards critical, transformative, transnational higher education and citizenry.

The new citizen is expected to deal with diverse positionings, distinct media in integrated manners approximating shape shifting portfolio people (GEE, 2004) what is equivalent to a multitask citizen as recommended by Cope and Kalantzis (2000). At the same time, from a more Brazilian perspective, he is aware of the fact that the teaching of English in Brazil together with its research and some professionals of this language constitute an issue that merits serious attention from the educators and society. Again, some generalization prevails in his thought.

Maybe the tourist portrayed in the song does not even know that Portuguese is one of the official languages in Brazil. Or, maybe he is aware of the fact that Brazil has become a multicultural country since 1988, when a law was passed recognizing the indigenous languages and, therefore, he asks himself what language would be desirable to use at that particular moment. 
This parody might be interpreted as a sign of the need to intervene in education drawing the listeners' attention to questions related to social inequity and mainly the question of epistemology "as the people are paying for this". In other words, Brazilians may speak English, but gradually. Meanwhile, the protagonist will starve. His claiming is imbued with a feeling of paradoxes intertwined with stabilities and changes; patience/hope ("Maybe they will learn it one day") and anxiety ("But while this does not happen I'm here starving").

One may wonder whether this statement could be hyperbolic. However, considering the number of schools, inadequate teacher education, insufficient number of hours dedicated to the English classes in English teaching from elementary schools to higher education (mainly in the public sector), it becomes clear that his epistemological and methodological concerns suggest an immense gap between the Brazilian desire to host a sports event and their lack of adequate preparation at least in terms of languages, as the images and the song from his short film indicate. This is an illustration calling for emergent multiliteracy pedagogies for phonology and phonetics, which is far from being a mere addition of ingredients. This view challenges the notion that there is only one way to speak English as attested by Ritchie ${ }^{10}$, among others.

The combination of Gil's work reflects his artistic repertoire to read, create, analyze, question and interpret his own performance. Such meanings go beyond the union of signs, standard English, static images, dynamic images, sound, speed, in short, all his capacities to combine different modalities appear in this show with many roles: musician, composer, guitar player, critic, movie maker, director and producer of his own work. It can be interpreted that his production is a way of reading/being in the world and with the word (FREIRE, 2005), of interrogating his own subjectivation (BIESTA, 2006), that is, his relationship between his intersubjectivities and of the others, changing traditional schooling practices, in which authorship was rarely legitimized.

Consequently, it seems to be high time schools recognized what learners bring in terms of knowledge, experience, abilities, talents, creativity and technical skills combined with theories acquired at university to produce tasks such as the one here highlighted. Video clips, such as the one here illustrated, include

10 "Standard English is spoken by only 15\% of the British population", says Harry Ritchie, author of English for the natives: discover the grammar you don't know you know. In: <http://www.theguardian.com/profile/harry-ritchie>. Access: 1 Jan. 2014. 
conceptions of dialogism and polysemy (BAKHTIN, 1999), hyper-textuality, multilingualism, hybridism as a discursive phenomenon to be disseminated, shared among others via YouTube, for example.

Gil's artistic, aesthetic and ethical attitude deconstructs the notion that learning should only come from top-down fashion, that is, from teacher to learner. It reconstructs a new system of hierarchy of undeniable importance of less unequal distribution of power while shaping a horizontal network of meaning due to the qualitative and integrative nature of his awareness of/capacity for phonological properties and phonetics realizations.

To this end, new technologies have been favoring dialogical exchanges of authorship, active agency in society. It is not, however, a matter of individual project or enterprise. On the contrary, what the video clip in question proposes is to share a dialogue dislocating the center of power (usually concentrated on mainstream forms of teaching-learning) towards the coexistence with the others. Gil appears to claim for more inclusive ways of being self-taught by taking initiative like his; he has learned English by listening to and playing music while adopting an open minded attitude to novelties.

When he self-questions, in the place of a tourist, what language he should use to be successful in his communication with the staff from the restaurant or bar, he reveals one possible alternative to promote changes: the strategy of questioning and self-questioning to gain not to miss opportunities As a critical consumer and producer/redesigner, he is likely to build up a new generation of learners able to better integrate phonology and phonetics, instead of simply establishing interfaces between them as largely independent and autonomous disciplines as attested by Ohala (1990).

\section{Words and Directions}

This study has reiterated educational practices at university with emphasis on how phonology and phonetics are inherent to any literacy practice (MORLEY, 1994; SEIDLHOFER; DALTON, 1995; ROACH, 2008; HOLLIDAY, 2009; JENKINS, 2009). In permitting learners to exercise their agency within their subjectivation rather than decontextualized repetition of the sound system, sentences or dialogues (which have little to do with their localness, sense of identity), multiple capacities in a repertoire of oral English varieties might prepare them to shuttle among bilingual, multilingual communities as required by the post-modern conditions to act and (in)act in digital societies. 
The learners also said they function best when the professor stimulated them to get networked through Facebook (they created a special closed page only for this purpose) or by emails so that the other peers could provide each other with immediate constructive feedback. Furthermore, this might accommodate unanticipated complexities and increase attention to constant fine-tuning with technology and human resources within the new ways of learning and meaning making.

Even more importantly is identifying what makes learners' practicing phonology and phonetics as social practices in ways that are developed, shared and assessed by themselves. And, from their productions, professors, as mediators, can assist them with instructional tools to enhance oralities as a reference instead of a quest for a fixed model.

\section{References}

APPADURAI, A. Modernity at large: cultural dimensions of globalization. Minneapolis: University of Minnesota Press, 1996.

BAKHTIN, M. Marxismo e filosofia da linguagem. São Paulo: Hucitec, 1999.

BIESTA, G. Beyond learning: democratic education for a human future. London: Paradigm, 2006.

BRYDON, D. Desenvolvendo letramento transnacional por meio do ensino do inglês. In: TAVARES, R. R.; BRYDON, D. (Orgs.) Letramentos transnacionais: mobilizando conhecimento entre Brasil/Canadá. Maceió: Edufal, 2013. p. 29-38.

CANAGARAJAH, A. S. Reclaiming the local in language policy and practice. New York; London: Routledge, 2005.

CELCE-MURCIA, M.; BRINTON, D. M.; GOODWIN, J. M. Teaching pronunciation to speakers of other languages. Cambridge: Cambridge University Press, 2008.

COPE, B.; KALANTZIS, M. Multiliteracies: literacy learning and the design of social futures. UK: Psychology Press, 2000. 
CRYSTAL, D. The stories of English (eBook) Penguin. 2005. Available in: <http://www.waterstones.com/waterstonesweb/products/ david+crystal/the+stories + of +english+28ebook29/6405764/>. Access: 12 Jan. 2007.

DELEUZE, G.; GUATTARI, F. A thousand plateaus: Capitalism and schizophrenia. London: University of Minnesota Press, 1987.

FREIRE, P. Pedagogia do oprimido. 42. ed. Rio de Janeiro: Paz e Terra, 2005. GEE, J. P. Situated language and learning: A critique of traditional schooling. New York: Routledge, 2004.

GRADDOL, D. English next. Why global English may mean the end of English as a foreign language? UK: British Council, 2006. Available in: <http://www.britishcouncil.org/learning-research-english-next.pdf>. Access: 10 Oct. 2007.

GODOY, S. M. B. de; GONTOW, C.; MARCELINO, M. English pronunciation for Brazilians. The sounds of American English. São Paulo: Disal, 2006.

HOLLIDAY, A. R. English as a lingua franca: 'non-native speakers' and cosmopolitan realities'. In: SHARIFIAN, F. (Ed.). English as an international language: perspectives \& pedagogical issues. Bristol: Multilingual Matters, 2009. p. 21-33.

JENKINS, J. World Englishes. A resource book for students. London; New York: Routledge, 2009.

KACHRU, B. Models for non-native Englishes. In: KACHRU, B. B. (Ed.) The other tongue. Illinois: Urbana University of Illinois Press, 1982.

KALANTZIS, M.; COPE. B. New learning: Elements of a science of education. Cambridge: Cambridge University Press, 2012.

KRAMSCH, C. Context and culture in language teaching. New York: Oxford University Press, 1993.

KRESS, G.; VAN LEEUWEN, T. Reading images. The grammar of visual design. London; New York: Routledge, 2001. 
KUMARAVADIVELU, B. Understanding language teaching: From method to postmethod. Mahwah, NJ: Lawrence Erlbaum, 2006.

LADEFOGED, P. A course in phonetics. $4^{\text {th }}$. ed. Boston: Heinle \& Heinle Thomson Learning, 2001.

LANKSHEAR, C.; KNOBEL, M. New literacies. Changing knowledge and classroom learning. UK: Open University, 2005.

LODGE, K. A critical introduction to phonetics. London: Continuum, 2009.

MIGNOLO. W. Local histories/Global designs: Coloniality, subaltern knowledges and border thinking. Princetown, NJ: Princetown University Press, 2000.

MORGAN, B. Leitura 'errada' de paródia em um curso de Inglês para fins acadêmicos: implicações para os letramentos transnacionais? In: TAVARES, R. R.; BRYDON, D. (Orgs.). Letramentos transnacionais: mobilizando conhecimento entre Brasil/Canadá. Maceió: Edufal, 2013. p. 77-94.

MORLEY, J. Pronunciation pedagogy and theory: New views, new directions. TESOL, Bloomington, chap. 7, p. 111-118, 1994.

MONTE MÓR, W. Reading Dogville in Brazil: image, language and critical literacy. Language and Intercultural Communication, v. 6, is. 2, p. 124-135, 2006.

NEW LONDON GROUP. A pedagogy of multiliteracies: Designing social futures, Harvard Educational Review, v. 66, p. 60-93, 1996.

OHALA, J. J. There is no interface between phonology and phonetics: a personal view. Journal of phonetics, v. 18, p. 153-172, 1990. Available in: $<$ http://www.linguistics.berkeley.edu/ ohala/papers/no_interface.pdf $>$. Access in: 17 Sep. 2010.

PHILLIPSON, R. Linguistic imperialism. Oxford: Oxford University Press, 1992.

PENNYCOOK, A. The myth of English as an international language. In: MAKONI, S.; PENNYCOOK, A. (Eds.) Disinventing and reconstituting languages. Clevendon; Buffalo; Toronto: Multilingual Matters, 2007. 
RAJAGOPALAN, K. Linguistics and myth of nativity: comments on the controversy over 'new/non-native Englishes'. Journal of Pragmatics, v. 27, p. 225-231, 1997.

RAJAGOPALAN, K. The concept of 'World English' and its implications for ELT. ELT Journal, v. 58, n. 2, p. 111-117, 2004.

ROACH, P. English Phonetics and Phonology. A practical course. Cambridge: Cambridge University Press, 2008.

SEIDLHOFER, B.; DALTON, C. Pronunciation. London: Oxford University Press, 1995.

SHOHAMY, E. Assessment in multicultural societies: applying democratic principles and practices to language testing. In: NORTON, B.; TOOHEY, K. (Eds.). Critical pedagogies and language learning. New York: Cambridge University Press, 2004. p. 72-92.

SHOHAMY, E. Language policy: Hidden agendas and new approaches. New York: Routledge, 2006.

SILVA, T. C. Pronúncia do inglês para falantes do português brasileiro. São Paulo: Contexto, 2012.

SMITH, L. E.; RAFIQZAD, K. English for cross-cultural communication: The question of intelligibility. In: SMITH, L. (Ed.). Readings in English as an international language. New York: Pergamon, 1979.

STREET, B. Recent applications of new literacy studies in education contexts. Research in the Teaching of English, v. 39, p. 417-423, 2005.

TAKAKI, N. H. Leitura na formação de professores de inglês: a questão da reprodução de leitura no ensino de inglês. Jundiaí: Paco, 2011.

TAKAKI, N. H. Ética pelo diálogo em meio aos letramentos. Perspectivas para pesquisas de formação de alunos e professores de línguas. Calidoscópio, v. 11, n. 1, p. 53-62, jan./abr. 2013.

VAN LIER, L. The classroom and the language learner. London: Longman, 1988. 
ZIMMER, M.; SILVEIRA, R.; ALVES, U. K. Pronunciation instruction for Brazilians: Bridging theory and practice together. UK: Cambridge Scholars Publishing, 2009.

WIDDOWSON, H. G. The ownership of English. TESOL Quarterly, v. 28, n. 2, p. 377-389, 1994.

Recebido em: 04/02/2014

Aceito em: 02/04/2014 